Глуханич Олеся Мирославівна, викладач-методист Комунального закладу вищої освіти «Ужгородський інститут культури і мистецтв» Закарпатської обласної ради, голова циклової комісії музичного мистецтва

ORCID iD https://orcid.org/0000-0003-3707-7602

\title{
РОЛЬ УЖГОРОДСЬКОГО ІНСТИТУТУ КУЛЬТУРИ І МИСТЕЦТВ У РОЗВИТКУ ПРОФЕСІЙНОЇ МУЗИЧНОЇ ОСВІТИ ЗАКАРПАТТЯ
}

Мета роботи полягає у дослідженні історичної ролі Ужгородського інституту культури і мистецтв у становленні та розвитку професійної музичної освіти крізь призму взаємовпливу національних культур. Методологія дослідження передбачає використання історико-логічного, аналітичного, системного, порівняльного методів, що дозволяе розкрити, всебічно та детально проаналізувати вплив Ужгородського інституту культури i мистецтв на культурно-мистецьке життя Закарпаття та формування професійної музичної освіти. Наукова новизна статті полягає в дослідженні історичної ролі Ужгородського інституту культури і мистецтв. Вперше було здійснено грунтовний аналіз ролі навчального закладу у формуванні професійної музичної культури Закарпаття, завдяки чому було визначено роль впливу національних культур у професійній музичній освіті. Висновки: Ужгородський інститут культури і мистецтв має визначальний вплив на формування сучасної професійної музичної культури Закарпаття. Широка підтримка поліетнічних впливів національних культур, їх інтеграція в процес навчання дозволили залучити до отримання професійної освіти представників національних меншин краю. На сучасному етапі Ужгородський інститут культури і мистецтв є цілісною освітньою системою, що забезпечує ступеневість професійної мистецької освіти на Закарпатті.

Ключові слова: Ужгородський інститут культури і мистецтв, становлення та розвиток професійної освіти, полікультурні міжетнічні впливи, національні культури, ступневість мистецької освіти, професійна педагогічна школа.

Глуханич Олеся Мирославовна, преподаватель-методист Коммунального заведения высшего образования «Ужгородский институт культуры и исскусств»Закарпатского областного совета, председатель ичикловой комиссии музыкального искусства

Роль Ужгородского института культуры и искусств в развитии профессионального музыкального образования Закарпатья

Цель работы состоит в исследовании исторической роли Ужгородского института культуры и искусств в становлении и развитии профессионального музыкального образования сквозь призму взаимного влияния национальных культур. Методология исследования предполагает использование историко-логического, аналитического, системного методов, метода сравнения, что позволяет раскрыть, всесторонне и детально проанализировать влияние Ужгородского института культуры и искусств на культурную жизнь Закарпатья и формирование профессионального музыкального образования. Научная новизна статьи состоит в исследовании исторической роли Ужгородского института культуры и искусств. Впервые был осуществлен основательный аналіз роли ученого заведения в формировании профессиональной музыкальной културы Закарпатья, благодаря чему было определено роль влияния национальный культур в профессиональном музыкальном образовании. Выводы: Ужгородский институт культуры и искусств имеет определяющее влияние на формирование современной профессиональной музыкальной культуры Закарпатья. Широкая поддержка полиэтнических влияний национальных культур, их интеграция в процесс обучения позволили приобщить к получению профессионального образования представителей национальных меньшинств региона. На современном этапе Ужгородский институт культуры и искусств является целостной образовательной системой, что обеспечивает ступенчатость профессионального музыкального образования на Закарпатье.

Ключевые слова: Ужгородский институт культуры и искусств, становление и развитие профессионального образования, поликультурные межэтнические влияния, национальные культуры, ступенчатость музыкального образования, профессиональная педагогическая школа.

Glukhanich Olesya, Methodist Lecturer of the Municipal Institution of Higher Education "Uzhgorod Institute of Culture and Arts" of Transcarpathian Regional Council, Head of the Cycle Commission of Musical Arts

Role of Uzhgorod Institute of Culture and Arts in the development of professional music education in Transcarpathia

The purpose of the article is to study the historical role of Uzhgorod Institute of Culture and Arts in the formation and development of professional music education through the lens of mutual influence of national cultures. The

(C) Глуханич O.M., 2019 
methodological base consists of studies on the history of Transcarpathia, cultural studies of artistic processes, theoretical works, articles, materials, archival documents. The methodology of the study involves the use of historical-logical, analytical, systematic, comparative methods, which allows to reveal, comprehensively and in detail analyze the influence of Uzhgorod Institute of Culture and Arts on the cultural and artistic life of Transcarpathia and the formation of professional music education.The scientific novelty of the article is to study the historical role of the Uzhgorod Institute of Culture and Arts. For the first time, a thorough analysis of the role of the educational institution in the formation of the professional music culture of Transcarpathia was carried out, thus determining the role of the influence of national cultures in professional music education.Conclusions: Uzhgorod Institute of Culture and Arts has a decisive influence on the formation of modern professional music culture in Transcarpathia. Wide support for the multiethnic influences of national cultures, their integration into the learning process made it possible to attract representatives of national minorities of the region to receive professional education. At the present stage, Uzhgorod Institute of Culture and Arts is a holistic educational system that provides the degree of professional art education in Transcarpathia.

Keywords: Uzhgorod institute of culture and arts, formation and development of vocational education, multicultural interethnic influences, national cultures, degree of art education, professional pedagogical school.

Актуальність теми дослідження зумовлена відсутністю системних досліджень ролі навчального закладу у формуванні системи професійної освіти. Особливістю мистецького життя Закарпаття $є$ його поліетнічність та багатонаціональність. Вони формують особливі взаємовпливи та сприяють взаємозбагаченню культур. Відтак актуальним напрямом дослідження $\epsilon$ аналіз взаємовпливу національних культур у сфері професійної мистецької освіти, що дозволяє виявити регіональні особливості фахової освіти на сучасному етапі.

Аналіз досліджень і публікацій. На сьогоднішній день питання ролі навчального закладу у формуванні професійної музичної освіти в цілому та його вплив на розвиток музичної освіти через призму взаємовпливу національних культур у такому обсязі не досліджувалися. Основу дослідження становлять праці історичного та культурологічного характеру. Серед них - наукові праці та публікації Т.Росул, В.Мадяр, О.Грін, Я.Рак, Л.Мокану, Л.Микуланинець, Н.Піцур. Вони досліджували розвиток музичного мистецтва на Закарпатті, а також питання, пов'язані зі становленням музичної освіти. Так, у монографії Т.Росул «Музичне життя Закарпаття 20-30-х років XX століття» окремий розділ присвячений аналізу музичної освіти на Закарпатті у 20-30 роки XX століття. Зокрема, автор детально описує зародження професійної мистецької освіти при Ужгородській гімназії, учительських семінаріях, приватних музичних школах (скрипкова школа Гусара Ернста, школи Віри Ромішовської, Софії Дністрянської, Ж.Лендєла та інших)[6, 85-93]. Ці дослідження дають можливість проаналізувати перші кроки щодо зародження професійної музичної освіти на Закарпатті, а також вплив міжнаціональних та поліетнічних факторів на розвиток мистецької освіти.

Л.Мокану уклала збірник праць, присвячених питанням професійної музичної культури Закарпаття, у якому піднімаються питання виникнення перших державних музичних навчальних закладів у середині XX століття[5]. Питання розвитку державної освіти на Закарпатті також досліджували М.Данко, О.Грін, В.Мадяр-Новак та ін. Разом з тим, питання ролі навчального закладу в формуванні системи професійної музичної освіти залишилось малодослідженим. Також і аналіз полікультурного поліетнічного впливу на професійну освіту залишається недостатньо дослідженим. Саме тому вивчення ролі Ужгородського інституту культури і мистецтв у становленні професійної музичної освіти доцільно здійснювати крізь призму взаємовпливу національних культур.

Метою дослідження є визначення ролі Ужгородського інституту культури і мистецтв у становленні та розвитку професійної музичної освіти крізь призму взаємовпливу національних культур.

Виклад основного матеріалу. Початки професійної музичної освіти на Закарпатті можна віднести до 20-х років XX століття. Саме тоді почало активно розвиватися концертне життя на Закарпатті. Якщо наприкінці XIX століття центром музикування були переважно аматорські хорові колективи, то з початку XX століття (20-ті роки) в Ужгороді було утворено товариство любителів музики «Філармонія» [6, 62]. I якщо спочатку воно займалось виключно організацією концертів, а на його базі діяли хор та симфонічний оркестр, то з часом гостро постало питання організації музичної освіти для учасників товариства, а згодом і для всіх бажаючих.

У подальшому почали активно з'являтися приватні музичні школи, в яких могли навчатися талановиті діти та молодь. У першій половині XX століття на Закарпатті діяли музична школа при товаристві «Філармонія» під керівництвом С.Фенцика, Ужгородська скрипкова школа під керівництвом Г.Ернста, міська музична школа Н.Плотені, приватні школи В.Ромішовської, С.Дністрянської, Ж.Лендєла та інші [6, 86-87]. Однак, розвиток музичної освіти на цьому етапі гальмувався як відсутністю професійних педагогічних кадрів, так і відсутністю професійного навчального закладу, що готував би педагогів для музичних шкіл. 
Ця ніша була заповнена тільки наприкінці 40-х років, після приєднання Закарпаття до Радянської України. У 1946 році було створено Ужгородське музичне училище, а в 1947 році розпочинає навчання технікум підготовки культосвітніх працівників у м. Хуст [3]. Ці два навчальні заклади стали основою для подальшого розвитку професійної музики на Закарпатті. I якщо Ужгородське музичне училище з перших років свого існування займалося підготовкою професійних музичних кадрів для дитячих музичних шкіл області, то Хустський технікум підготовки культосвітніх працівників пройшов довгий тернистий шлях, а якому були і зміна назви навчального закладу на Хустське культурно-освітнє училище (1961 рік), i переїзд до м. Ужгорода (1985 рік), і подальша зміна назви навчального закладу спочатку на Ужгородське училище культури (1990 рік), Ужгородський коледж культури і мистецтв (2007 рік), Ужгородський інститут культури і мистецтв (2019 рік) [3]. 3 кожною зміною назви відбувались і якісні зміни в кількості навчальних спеціальностей та спеціалізацій. Так, якщо на початку своєї роботи Хустський технікум підготовки культосвітніх працівників здійснював навчання лише однієї академічної групи бібліотекарів, то вже у 1948 році було відкрито клубну спеціальність, а в 1961 році - спеціальності хорового диригування та народних інструментів. У подальшому кількість спеціальностей та спеціалізацій збільшувались, а якість освіти невпинно зростала.

На сьогоднішній день в Ужгородському інституті культури і мистецтв готують фахівців за освітньо-кваліфікаційними рівнями «Бакалавр» та «Молодший спеціаліст». На ОКР «Бакалавр» навчають студентів за п'ятьма спеціальностями: «Музичне мистецтво», «Сценічне мистецтво», «Хореографія», «Менеджмент соціокультурної діяльності», «Інформаційна, бібліотечна та архівна справа»[8]. Станом на сьогоднішній день успішно працюють дві кафедри - соціокультурної діяльності та мистецьких дисциплін. Кафедру соціокультурної діяльності очолює доктор історичних наук, професор Ільганаєва Валентина Олександрівна, кафедру мистецьких дисциплін очолює кандидат мистецтвознавства Андрійцьо Василь Михайлович.

На ОКР «Молодший спеціаліст» навчають студентів за спеціальностями «Музичне мистецтво», «Менеджмент соціокультурної діяльності», «Сценічне мистецтво», «Хореографія», «Інформаційна, бібліотечна та архівна справа». Успішно працює 7 циклових комісій - музичного мистецтва, менеджменту СКД, сценічного мистецтва, режисури ВТЗ, хореографії, інформаційної, бібліотечної та архівної справи, гуманітарних дисциплін [8].

Гордістю навчального закладу $є$ творчі колективи, серед яких слід відзначити народний аматорський хоровий колектив, народний аматорський вокальний ансамбль, народний аматорський фольклорний ансамбль народних інструментів «Маки», народний аматорський ансамбль танцю «Кольори Карпат», народний фольклорний ансамбль угорського танцю «Сонях», ансамбль сучасного танцю «Акцент», танцювальний колектив класичної хореографії «Натхнення», танцювальний колектив «Вітраж»[8]. Вони систематично беруть участь у різноманітних концертних заходах, конкурсах та фестивалях, представляючи мистецтво Закарпаття далеко поза його межами.

На сьогоднішній день Ужгородський інститут культури готує професійні творчі кадри для всіх без винятку творчих установ та колективів Закарпаття. Наші випускники працюють в Закарпатській обласні філармонії, в Закарпатському народному академічному хорі, Закарпатському академічному обласному українському музично-драматичному театрі імені братів Юрія-Августина та Євгена Шерегіїв, в мистецьких навчальних закладах різних рівнів. Орієнтація на віддалені райони Закарпаття, наявність хорошої матеріально-технічної бази дозволили випускникам Ужгородського коледжу культури i мистецтв (а з 2019 року - Ужгородського інституту культури і мистецтв) заповнити прогалину з фахових кадрів для професійних культурно-мистецьких установ та навчальних закладів краю.

Слід зазначити, що вплив навчального закладу на формування професійної музичної освіти Закарпаття завжди був помітним. У повоєнні роки тільки розпочалась робота по створенню мережі початкових музичних навчальних закладів у різних районах області. I якщо у містах Ужгород та Мукачево справа 3 організацією дитячих музичних шкіл стояла досить непогано, оскільки ще до війни там діяли приватні музичні школи, то в інших районах і більш дрібних населених пунктах катастрофічно не вистачало професійних кадрів для комплектації музичних шкіл педагогами. Великою мірою підготовка фахівців покладалася на Ужгородське музичне училище. Однак, Хустське культурно-освітнє училище зробило свій великий внесок у цю справу. По-перше, розташування в глибині Закарпатської області, далі від культурних центрів Ужгород і Мукачево зробили музичну фахову освіту більш доступною для сільської молоді, яка не завжди мала можливість їхати на навчання до Ужгорода. По-друге, наявність гуртожитку та хороша матеріально-технічна база робили навчання доступним для обдарованої учнівської молоді з незаможних верств населення. По-третє, Закарпаття - край багатонаціональний, поліетнічний. Тут компактно проживають національні меншини угорців, румунів, словаків, що породжує певні мовні бар'єри. Зокрема, угорськомовне населення проживає компактно в населених пунктах Ужгородського, 
Берегівського, Виноградівського районів, їх діти навчаються в школах з угорською мовою навчання. I в повоєнні роки навчання саме представників цієї національної громади становило певні труднощі. Саме в підтримці багатонаціональних особливостей Закарпаття, сприянні отриманню освіти представниками національних менших, розвитку полікультурних впливів полягала велика просвітницька місія Хустського культурно-освітнього училища, а згодом - Ужгородського училища культури і мистецтв, що стало попередником Ужгородського інституту культури і мистецтв. 3 90-х років XX століття при Ужгородському училищі культури за підтримки управління культури Закарпатської обласної державної організації та товариства угорської культури діяло угорське відділення, на якому навчались студентипредставники угорської національної меншини, навчання велося на рідній для студентів угорській мові, 3 поступовою інтеграцією в український освітній простір. Так, якщо першокурсники з угорськомовного регіону мали певні проблеми 3 володіння українською мовою, то за чотири роки навчання вони інтегрувалися в мовне середовище настільки, що державні іспити на 4 курсі всі складали державною мовою.

Слід зазначити також, що Ужгородський коледж культури і мистецтв завжди підтримував та розвивав поліетнічні та полікультурні особливості нашого краю. Надаючи можливість студентампредставникам національних меншин навчатись, поступово інтегруючись в українське мовне середовище, створюючи сприятливі умови для розвитку всіх без винятку культур, навчальний заклад постійно збагачував і розвивав своє творче розмаїття. Творчі колективи, що діють на базі Ужгородського інституту культури і мистецтв, мають в репертуарі твори як українських композиторів, так і твори композиторів національних меншин. Поруч з народним аматорським фольклорним ансамблем народних інструментів «Маки» впродовж багатьох років діяв народний ансамбль угорських народних інструментів, а поруч 3 народним аматорським ансамблем танцю «Кольори Карпат» успішно працює народний фольклорний ансамбль угорського танцю «Сонях». У репертуарі вокальних творчих колективів - угорські, румунські, словацькі, сербські, македонські, польські, чеські пісні.

Випускники Ужгородського інституту культури і мистецтв працевлаштовуються в музичних школах, школах естетичного виховання, загальноосвітніх школах, клубних установах краю. Вони щедро діляться здобутими знаннями зі своїми вихованцями. Завдяки мудрій політиці підтримки національних меншин, збереженні полікультурних та поліетнічних традицій краю, їх інтеграції в освітній процес професійна музична освіта стала доступною для різноманітних верств населення багатонаціонального Закарпаття. Враховуючи поліетнічну специфіку краю, викладачі Ужгородського інституту культури i мистецтв вибудовують свою роботу таким чином, щоб забезпечити рівні умови для отримання освіти представникам всіх національностей, що населяють Закарпаття, дозволяючи представникам національних меншин поступово та безболісно адаптуватися та інтегруватися в єдине мовне середовище навчання, зберігши при цьому свою етнічну автентичність.

Висновки. Детальний аналіз роботи Ужгородського інституту культури і мистецтв та його попередників, починаючи зі створення Хустського технікуму підготовки культосвітніх працівників, показав, що на всіх етапах функціонування та розвитку навчальний заклад зберігав та розвивав поліетнічні та полікультурні особливості регіону, забезпечував можливість представникам національних меншин навчатись та поступово інтегруватись до українського мовного простору. Орієнтація на периферійні райони Закарпаття, проведення хорошої профорієнтаційної роботи, створення хорошої матеріально-технічної бази забезпечили наявність студентів з різних куточків Закарпаття i, як наслідок, забезпечення високопрофесійними кадрами всіх населених пунктів області. Постійне самовдосконалення, реорганізація у відповідності до викликів сьогодення, оновлення навчальних планів, розширення кола спеціальностей, відкриття ОКР «Бакалавр» сприяють тому, що Ужгородський інститут культури і мистецтв на сьогоднішній день є справжнім лідером у сфері професійної мистецької освіти краю.

\section{Лimepamypa}

1. Грін О.О. Професійне музичне мистецтво Закарпаття XIX - першої половини XX століття: історичний аспект. Ужгород: Госпрозрахунковий редакційно-видавничий відділ управління у справах преси та інформації. 2004. 160 с.

2. Данко М. Державна музична освіта на Закарпатті та іiі досягнення за останні півстоліття. Професійна музична культури Закарпаття: етапи становлення. Ужгород, 2010. Вип. 2. С.21-26.

3. Історія Ужгородського інституту культури і мистецтв. URL: https://institute-culture.uz.ua/prokoledzh/istoriia (дата звернення: вересень 2019)

4. Микуланинець Л. М. Етнокультурологічне становлення професійної музичної культури Закарпаття у другій половині ХХ століття. Мистецтвознавчі записки : зб. наук. праць. Київ: Міленіум. 2009. Вип. 15. C. 184-188. 